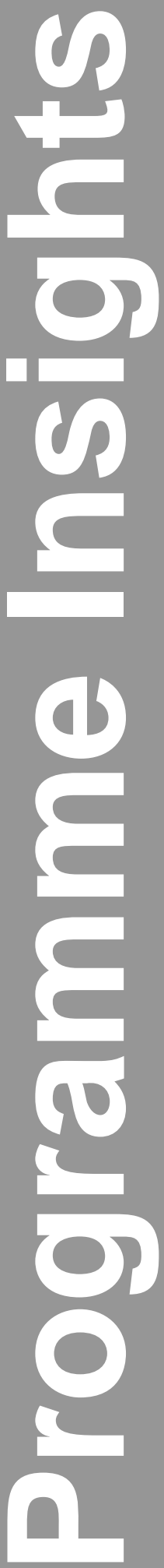

3. Leading by
Example

\title{
How cities came to link rural producers with urban food markets in Colombia
}

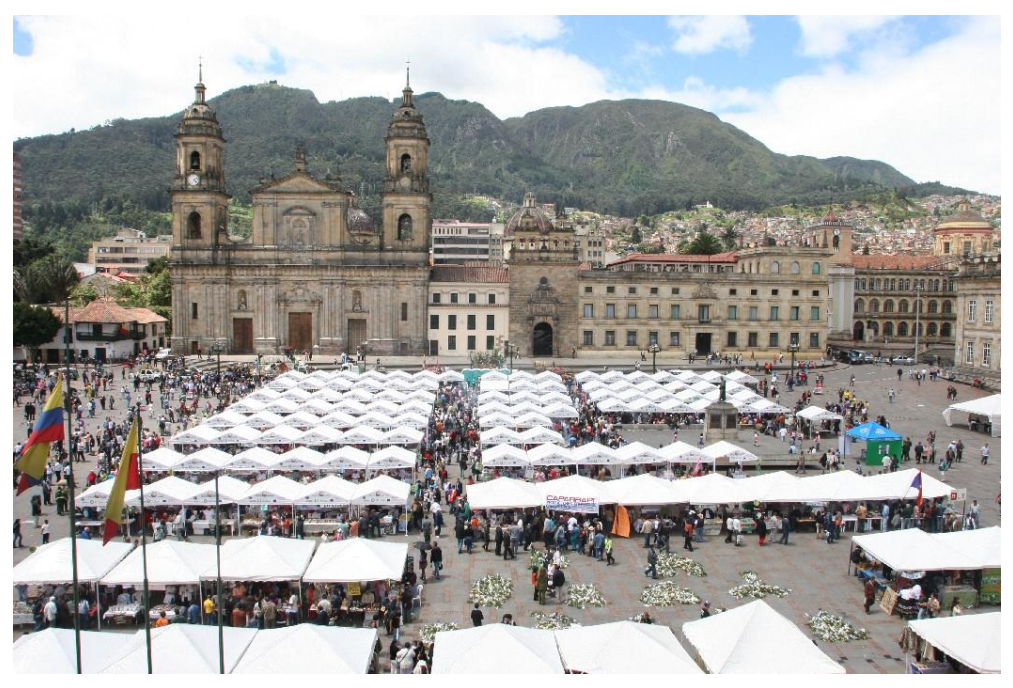

Due to advocating the local government, more than 2,000 small producers are now able to sell their produce directly in Bogotá, getting better prices for them as well as for urban consumers.

C Jesus Abab Colorado

Following decades of conflict and violence, millions of small farmers in Colombia remain economically excluded and trapped in poverty. Many city-dwellers and policy-makers are ignorant of their problems, or are not interested. However, an initiative in the capital Bogotá has strengthened links between rural and urban communities and has demonstrated that small producers can become political and economic actors - and that the small producer economy is not only viable, but can be an important part of the solution to urban food insecurity. To achieve this, small producers, NGOs, and municipal authorities have worked together, building a successful advocacy strategy based on a practical working model of access to markets.

\section{(8) Oxfam}




\section{Introduction}

For the past 40 years, Colombia has suffered from violent conflict involving illegal armed groups who, from the 1980s onwards, have colluded with the country's drug cartels. This has led to gross violations of human rights, fuelled to a large extent by social inequality, poverty, and a lack of economic opportunities in rural areas. Peace talks between the Government and the main left-wing rebel group, FARC, collapsed in 2002. The recent process designed to demobilize the paramilitary groups has led to a culture of impunity, the concentration of land ownership, ${ }^{1}$ and increasing control of political parties and institutions by members of these groups. ${ }^{2}$ The appropriation of land and natural resources is one of the main drivers of the conflict in Colombia. There is a need to distribute at least seven million hectares of land in order for rural households to generate enough income to meet their basic needs (CEPAL). ${ }^{3}$

Together with the political violence, drug-related crime has made Colombia one of the most violent countries in the world (BBC). ${ }^{4}$ Armed conflict has displaced more than three million people (Acción Social), 5 and thousands have died. Throughout the country - and especially in rural areas - the rule of law is weak, corruption is rife, and human rights violations go unchallenged.

Despite the years of violence, Colombia has maintained long-term economic growth and is one of the largest economies in Latin America. At the same time, however, inequality has risen and it is now the third most unequal country in Latin America and the ninth most unequal in the world (Conpes Social). ${ }^{6}$ Rural areas in particular have lagged behind. While an estimated 39.8 per cent of Colombia's urban population live in poverty, poor people in rural areas represent 65.2 per cent of the total population (DANE/DNP). ${ }^{7}$ Rural women are particularly disadvantaged (MERDP), 8 as are as indigenous communities.

To increase their economic alternatives and to boost their incomes, some small-scale farmers (campesinos) have turned to coca cultivation. In 2007, the number of households involved in growing the crop increased by 19 per cent to 90,000 (UNODC). ${ }^{9}$ In its attempts to control the drug trade, the government has focused its efforts on pursuing the weaker part of the supply chain - the coca growers while not putting enough effort into capturing cartel members. It is spraying illegal crops, but this has been costly and ineffective, and has damaged legitimate crops and the livelihoods of hundreds of innocent families (Ibid.). ${ }^{10}$

'Because of the fumigations we have lost our crops, especially the plantains which are our main source of food and the crops we sell papaya, watermelon, and cantaloupes - from which we earned a living. Now three of my seven children have gone to the mountains, 
to the coca crops,' said one female small farmer of Afro-Caribbean descent, who in order to protect her own safety wished to remain anonymous.

\section{Box 1. The lure of the coca trade}

'What happened with maize here was that imported maize started to come in at very low prices and we small producers could not lower our prices so much, so this motivated many producers to start to grow coca,' explains one small farmer from Cauca, who wishes to remain anonymous for security reasons.

Another says: 'Since we did not own land, my children had to work on the nearby farms where they earned around $\$ 7$ a day. If they work harvesting coca crops they can earn $\$ 15$ a day. But it scares me: if they start working with coca they may join the guerrillas. I am participating in this programme because I am trying to make a better life for my children.'

As well as lacking public investment, ${ }^{11}$ rural populations lack a strong voice to speak for them. Although there are some strong indigenous movements, there are few effective civil society organizations (CSOs) or mechanisms capable of holding the state to account. In addition, in the 1990s the economy was opened up to foreign competition without first putting in place measures to protect small farmers, and today huge numbers of people in rural areas are struggling to make ends meet.

In some ways, there is a sense of Colombia being a country of two realities: in more affluent areas of the cities it is possible to live completely unaffected by the brutal conflict, while in rural areas violence, intense poverty, and a widespread sense of exclusion and disempowerment are daily challenges for millions of people.

\section{Making the case for change}

Small-scale agricultural producers supply 35 per cent of the food consumed in Colombia (Forero), ${ }^{12}$ a proportion that rises to 67 per cent in the capital Bogotá (Food Master Plan). ${ }^{13}$ However, the important role that small-scale producers play in the economy is not reflected in their incomes: millions of people reliant on small-scale agriculture live in poverty and more than five million suffer from malnutrition, in one of the most biodiverse and fertile countries in the world (FAO). ${ }^{14}$

This is due in part to the weak position of small farmers in marketing their produce. Constraining factors include variable and limited access to land and markets, poor information and quality control, and lack of experience and power in negotiating market transactions. Much of the produce sold in urban markets is handled by commercial intermediaries, who buy from individual producers at low prices and then make a profit without adding any value to the products. 
In 2005, Oxfam GB embarked on a programme aimed at helping to overcome the barriers that prevent small farmers from getting fair returns from markets and at creating fairer commercial links between poor rural and urban populations. Its main implementing partner was the Instituto Latinoamericano de Servicios Legales Alternativos (ILSA), which works with peasant organizations and rural communities to protect the rights of poor rural people. ${ }^{15}$ The other key partner was the Comite de Interlocución Campesino y Comunal (CICC), a committee that helped to co-ordinate and lead the project. ${ }^{16}$ The idea was to support small-scale rural producers, especially women, by strengthening their role in the rural-urban food supply chain. At the same time, the intervention would make good-quality food available at affordable prices for low-income families in urban areas a win-win situation for both.

Oxfam and its partners wanted to document practical examples that would persuade government that the campesino (peasant) economy could become a driver of development, providing a route to economic growth and poverty reduction. By demonstrating that small-scale producers were worth investing in, they also hoped to gain legitimacy to lobby the US Congress on the potentially negative impacts of the US-Colombia Free Trade Agreement, which was being negotiated at the time. Social organization and advocacy to influence public policy were key components of the programme. In 2003 Oxfam supported ILSA's organization of the Agrarian Congress, which brought together more than 5,000 leaders from all over the country and led to the design of the Agrarian Mandate - the first commonly agreed agenda for the rural sector.

\section{Box 2. Opening up dialogue, building trust}

At the outset of the project, Oxfam and ILSA conducted research to obtain clear data on the potential of the peasant economy (ILSA). ${ }^{17}$ They consulted with academics, political leaders who had worked with peasant movements, experts on rural women and their role in social movements, rural leaders, peasant organizations, INGOs, NGOs involved in agroecology, and peasant farmers, both men and women, with whom Oxfam was already working. As well as consulting with potential allies, the programme partners wanted to hear the opinions of those who did not necessarily share their views - for example, government officials who thought that the peasant economy was no longer viable and had been 'sent to the scrap yard'.

Consulting with opponents proved to be very useful, both in terms of gathering information and in gauging the levels of prejudice and mistrust harboured by public institutions and officials towards peasant farmers. Officials frequently expressed opinions such as, 'The peasants are lazy, they support the armed groups, they take advantage of the drug mafias, and take their cut growing coca.'

This made it abundantly clear that the problem was not simply one of information, but also one of trust and goodwill. Oxfam and ILSA realized that their work had to involve building trust between public officials and peasant farmers. As it turned out, this proved to be the single most important factor in the success of the project. 


\section{Seizing the opportunity}

Colombia's national government showed little interest in Oxfam's proposal. In 2004, Oxfam lobbied the Ministry of Agriculture, but officials claimed that small-scale producers were already covered by its policies. Official data showed, however, that the Ministry considered 'small' producers to be those who owned up to 50 hectares of land. Consequently, Oxfam decided to adopt a strategy that would 'by-pass' the national government, instead supporting partners to lobby the food security programmes of the local authorities running Colombia's main cities, such as Bogotá and Cali.

The municipality of Bogotá ranks second in the country in terms of executive power after the national government itself and is Colombia's biggest food market, with seven million consumers. Here Oxfam and its partners were able to capitalize on an important opportunity: in 2004, the Office of the Mayor of Bogotá had begun to speak openly for the first time about poverty levels in the city and the need to make food accessible to all its inhabitants. It had begun to draw up a 'Food Supply Master Plan', but this failed to recognize the potential of small producers.

Neither small producers nor the wider public knew much about the city government's plan, but Jesus Anibal Suarez, the head of ILSA's Agrarian Programme and a leader well respected by peasant organizations, managed to disseminate the main ideas contained in it. The plan was based on obtaining food supplies for the minimum possible price, but it did not consider the needs of producers or the potential for reducing rural poverty. If the plan were to favour large food marketing companies rather than small farmers, it would risk destroying the livelihoods of thousands of small producers reliant on selling their produce in Bogotá. Instead of a minimum price, ILSA, rural organizations, and Oxfam proposed that the plan should be based on a 'fair price' principle.

In formulating its strategy, ILSA drew on past experience of consensus-building and called together the organizations that had participated in the Agrarian Congress. Based on this collective agenda (the Agrarian Mandate), the organizations founded in 2003 the Comite de Interlocución Campesino y Comunal (CICC), a body that united 12 peasant and community organizations with some 1,000 members between them. CICC's aim was to influence Bogatá's food security policy. In forging a broad alliance capable of making change happen, vital lessons were learned about the importance of partners having clear agendas and the need for credible leaders within local communities.

It is rare in Colombia that public institutions and social organizations engage in constructive dialogue, due to mutual distrust, so it was very difficult to convince the Mayor of Bogotá to sit down with the campesinos to discuss their proposals for the design of the plan. 
Nevertheless, ILSA and the CICC persevered, and ILSA was able to bring together more than 100 people at a series of meetings to agree on proposals to lobby the Mayor. As a result, the producers formulated a number of clear demands, designed to fit with the Mayor's own agenda. Their main message was: 'We want to be part of the solution to hunger in Bogotá. Our products can solve the city's food problem.' This clear and positive message was very important in influencing the attitudes of city officials and in encouraging other individuals and organizations to join the campaign.

However, at this point the Mayor's Office was still sceptical of the peasants' ability to supply food in an efficient way. Oxfam, ILSA, and the CICC therefore set out to make the producers' voices heard and to demonstrate their organizational capacity in a creative way. They organized farmers' markets in strategic locations around the city such as Plaza Bolívar, the city's main square - to coincide with key moments in discussions about the food supply plan.

Around 200 producers participated in each market and drew a great deal of interest from urban consumers, both in the excellent quality of their products and the attractiveness of their prices. Women played a fundamental part in the process, participating in the markets and in campaigning activities aimed at building public support. They showed great determination in overcoming obstacles to market access and boldness in adopting new strategies. One key city government official in charge of the plan who visited a market confessed to being surprised by the level of organization and capacity on display. The campaign demonstrated to officials that the issue was of interest to a broad section of the population.

\section{Forging new alliances}

The Mayor's Office was beginning to recognize the potential of small producers, but there was still no proper forum in which to debate the plan. ILSA therefore simultaneously targeted three different, but equally important, actors in an attempt to open up dialogue and influence the design of the Food Supply Plan and the Food Security Policy for Bogotá: ${ }^{18}$ the local authorities in the municipalities where producers were located; the private sector company Corabastos, Colombia's biggest food distributor; and Bogotá's Municipal Council, which had the political power to push the Mayor to open up a dialogue with the producers' organizations in formulating the food supply plan.

ILSA found that the municipal councils in the producing areas - who as public bodies could engage in dialogue with officials in the city knew little about the food supply plan. It persuaded 50 councils, of all political complexions, to sign a joint communiqué calling on the Bogotá city government to consult with producers about its design. ILSA also held discussions with Corabastos, which handled most of 
the food sold in shops all over Colombia. This was a bold move, as the firm has the greatest power in the country to set food prices and could be seen as a key actor in preventing small producers from achieving greater power in markets. However, in a groundbreaking tactical alliance, ILSA encouraged the company to use its influence with local politicians, pointing out that it risked losing out itself if the Mayor's Office excluded it from the food supply plan. This was the first time that small producer organizations had formed a tactical alliance with this company.

In April 2005, ILSA arranged for a leader of the campesinos to directly address the Municipal Council, the first time that this had happened. Simultaneously, a farmers' market was organized by ILSA, Oxfam, and CICC in the public square outside the Council building, to symbolize the importance of small producers to the city's food security. In his address, the producers' representative invited councillors to visit the market at the end of the session. Also that day, Colombia's highest-circulation newspaper, El Tiempo, published a letter signed by the 50 municipal councils stressing the importance of involving small producers in the food supply plan. The result was that, the same day, the Municipal Council committed to push the Mayor to open up the city's food security plan to public discussion. Subsequently, the Council organized a series of public discussions that initiated dialogue between the Mayor and producers in the surrounding municipalities.

At ILSA's suggestion, discussions were held in the producing areas, via decentralized sessions of the Council. This allowed officials to see for themselves how producers lived, and enabled more producers to participate directly in the sessions. After a series of regional consultations, the Mayor of Bogotá finally agreed to revise the city's plan from one based on the lowest possible price to one based on fair prices. The Mayor also agreed to invest in enabling small producers to supply the city in an efficient way. An implementing committee was set up to manage the supply plan and to make decisions on how and when to invest funds; it was agreed that this committee should include two representatives of the producer organizations, giving campesinos a direct say in the way that the plan was implemented.

The Bogotá Food Policy was finally approved by the city, covering the period up until 2015. It expressed clearly the need to support small producers to access the city's food market as a means of improving their living conditions, as well as facilitating access to food for poor urban consumers. This new approach has the potential to benefit both the seven million inhabitants of Bogotá and the thousands of producers living in the surrounding areas. 


\section{Consolidating and scaling up the initiative}

The work was still not finished, however: despite these real achievements, Oxfam, ILSA, the CICC, and the producers wanted to see concrete investments from the Mayor's public budget to turn the promises into real political action. Furthermore, with mayoral elections due across the country in October 2007, there was a risk that the gains and promises might be lost with a change of officials. It was important to ensure that future budgets guaranteed resources and that the supply plan could be demonstrated to be workable.

To help achieve this, the partners pursued a number of strategies simultaneously. First, ILSA and Oxfam supported the CICC organizations to elect their two representatives to the implementing committee of the Food Supply Plan. Second, in partnership with the Municipal Council they set up a pilot marketing project called 'Mercados Campesinos' (farmers' markets). Oxfam played an important role in mediating between officials and the producers' organizations, as at that time there was still much mistrust between them. At last, however, the pilot project was implemented, managed by ILSA. It initially involved more than 1,000 producers organized into local marketing groups, which helped to build capacity and generate economies of scale.

Third, as the elections approached, the CICC targeted candidates who expressed support for their campaign, even convincing some to sign legally binding commitments. Persuaded by the success of the Mercados Campesinos pilot project, most candidates with the best chances of winning a seat included the issue in their manifestos, which helped to create a solid base of support once the new municipal administrations were formed.

Since then, more than 30 municipalities in the area around Bogotá, seeing the success of the markets in the city, have decided to organize their own local markets. Bogotá's Mayor has signed contracts with five other regional governments to increase rural investment for food production. To ensure that these gains are sustainable, ILSA, with support from Oxfam, is lobbying another 40 municipal councils to ensure that they approve public policies supporting small producers, together with technical support and assets for accessing markets.

Following this success, Oxfam aims to scale up the model of smallholder involvement by replicating the initiative in Medellín and Cali, the two other mayoral cities in Colombia. Oxfam has shared its experience with officials in Medellín, who are currently designing their own food supply policy, as well as with the Mayor of Cali. Indigenous organizations in the southwest of the country have initiated a lobbying process similar to the one employed in Bogotá, pursuing dialogue with officials and organizing markets in the city. 
At national level, it has proved very difficult for the programme to influence changes in either policy or investment. However, one avenue that offers potential to influence national-level politicians has been opened up through engagement with US Congressmen who have an interest in international trade agreements (see Box 3 ).

\section{Box 3. Informing advocacy at the international level}

The Colombian government has attempted to negotiate free trade agreements (FTAs) with partners such as the USA and the EU, but its efforts have failed due to the country's continuing human rights violations and unstable security situation. An FTA negotiated with the USA during the Bush administration has been held up by the US Congress, until the Colombian government can guarantee that the rights (and lives) of trade unionists will be respected.

It is essential to protect the interests of small-scale producers under any such agreement, and Oxfam has lobbied the US Congress to consider the impact that such a deal might have. In a country where 40 per cent of basic foodstuffs are produced by small farmers it would be wrong, argues Oxfam, to approve an agreement that would push them out of the market. Such a move would only serve to fuel armed conflict and the cultivation of illicit crops.

Oxfam's programme in Colombia, through initiatives such as the Mercados Campesinos project, shows that, with the right policies, it is possible to improve producers' incomes and to turn a peasant economy into a driver of development. Oxfam has proposed to the US Congress that the treaty should not be approved as it stands, but instead that it should include measures to protect Colombia's small-scale producers and food security in general.

Oxfam and its partners in the USA and Colombia have already shared the results of their successful initiative with Congressmen and have invited them to visit Colombia to see the reality and to hear small producers' proposals for themselves. It is hoped that a practical example of smallholder capacity, with clear benefits, will convince decision-makers of the economic and social importance of small-scale agriculture.

\section{The programme's impact}

- As a result of the advocacy undertaken by Oxfam and its partners, a wide social movement representing small-scale farmers is developing, leading to changes in policy, market systems, and consumer behaviour.

- As of December 2009, the Mercados Campesinos project had benefited more than 2,000 producers with less than 5 hectares of land each. Their total sales over three years have been worth more than $\$ 3 \mathrm{~m}$. These sales have represented a real benefit for small producers: monitoring by Oxfam and ILSA has shown that the average net increase in prices for farmers is 64 per cent. 
- Fifty municipal groups have now been constituted and these groups are growing; the only requirement for a prospective member is to be a small producer willing to sell directly to the city. These local groups collect together farmers' produce and jointly cover the costs of transporting it to the city.

- Urban consumers have also benefited, with prices averaging 34 per cent lower than in large chain supermarkets. This 'win-win' outcome demonstrates the efficiency of producers organizing themselves in order to access urban markets.

- The strategy developed by Oxfam, ILSA, and the CICC played a key role in formulating the Bogotá Food Supply Master Plan and the Food Security Policy, which have been approved until 2015 and are committed to a 'fair price' principle.

- As a result of the advocacy work, the programme has also leveraged an additional investment of $\$ 720,000$ from the Mayor of Bogotá, with commitments to further develop market infrastructure to boost rural-urban trade.

- The process of working together with the Mayor of Bogotá and building ownership of the action within government has had significant implications for sustainability and for the process of self-replication. The Mayor himself is taking forward the process with mayors in five other regions.

- Women interviewed by external evaluators said that the programme had had a great impact on their daily lives. Most of them had played an active role in advocacy activities and now feel more confident about marketing and selling their produce.

\section{Box 4. Real economic alternatives for small producers}

'Before, it was difficult just to buy enough food. But now, I have enough money to pay for my children's education,' says one female small-scale producer from Boyacá, a rural area northeast of Bogotá.

'I realize that I can earn a living, that I am capable, and now I am thinking about bigger things. I'm going to begin raising rabbits and chickens as a serious business. Now we know we can do it.'

\section{Challenges and opportunities}

Despite the programme's success, challenges remain. There is still an urgent need for other local governments to invest in small-scale producers. A real national policy is needed to guarantee small farmers' access to land and other economic activities, as well as to improve security, so that community members are able to defend their rights without being threatened or even killed. 
Social organizations need further strengthening to be able to build on their work in defending the rights of rural people and giving them a voice. There is also a need for effective public forums where the opinions of such organizations are taken seriously and are considered in the design of public policies. In addition, wider campaigns to sensitize public opinion on the reality of life in rural areas have the potential to improve the engagement of consumers (and voters) with the problems that face small-scale producers, and to help in the search for solutions.

\section{Conclusion}

One of the key drivers of Oxfam's programme in Colombia was to help create legal economic alternatives for small producers, by strengthening civil society and by tackling poverty and the lack of economic opportunities that lead to inequality and exclusion. Real opportunities for sustainable livelihoods reduce the incentive for people in rural areas to join armed groups or to become involved in illegal coca supply chains.

The programme has provided an example of how to carry out evidence-based advocacy, while achieving real changes in people's lives. It has succeeded in developing important links between partners and producers, has achieved a wider impact through influencing policy processes and political leaders, and has demonstrated the capacity of small-scale farmers - especially women - to gain direct access to urban markets and to participate in better commercial linkages. The outcome has been fairer prices for both producers and consumers.

The process has also provided important lessons for Oxfam and its partners about how change happens. These include the importance of focusing interventions and designing clear but flexible advocacy strategies, aimed simultaneously at authorities at different levels. It has emphasized the importance of engaging in dialogue not only with allies but also with adversaries, and of bypassing national government where this is acting as a 'blocker'. It also shows the importance of working 'where the energy is' - i.e. supporting the agendas of existing social organizations that are able to identify opportunities and capitalize on them when they arise. Strong and accountable social leaders, together with well-organized communities, can help to build connections with decision-makers, resulting in positive changes in public policies.

In summary, the process demonstrates the value of using a wellconstructed case to convince others that change is possible. 


\section{Notes}

${ }^{1}$ Just 0.5 per cent of land owners in Colombia own 60 per cent of the land, and statistics show a worrying trend of accelerating land concentration over the past decades. The proportion of properties of more than 200 hectares increased from 47.1 per cent of the total land stock in 1984 to 68.3 per cent in 2000 , and to 76.1 per cent in 2005 . At the same time, the proportion of properties of less then 3 hectares decreased from 2.9 per cent of the total land stock in 1984 to 1.9 per cent in 2005. Statistics for 1984 and 2000 from Kalmanovitz, Salomón and López Enciso, Enrique, "Tierra, conflicto y debilidad del Estado en Colombia" [Land, conflict and State weakness in Colombia"], Observatorio de la Economía Latinoamericana, 2005, issue 44. Statistics from CID-UN, based on calculations by Instituto Geográfico Agustín Codazzi. Source: CID-UN (2006) Bienestar and Macronomía 2002 06, Bogotá http://www.doteccolombia.org/index.php?option=com content\&task=view\&id=2064

${ }^{2}$ Sixty per cent of the Senate consists of political parties close to the Government (known as partidos Uribistas). Since June 2009, when the process of demobilizing the paramilitaries began, 67 per cent of these senators have been judicially investigated for links with paramilitary groups or drug traffickers. Source: Fiscalía General de la Nación y la Corte Suprema de Justicia (General Prosecutor's Office of the Nation and the Supreme Court).

${ }^{3}$ CEPAL. http://www.eclac.org

${ }^{4}$ BBC News Country Profile, http://news.bbc.co.uk/1/hi/world/americas/4528631.stm

${ }^{5}$ Ten per cent of the country's population have been displaced at least once. http://www.accionsocial.gov.co

${ }^{6}$ The Gini index increased from 0.544 in 1996 to 0.563 in 2003. 'Encuesta de Hogares' (Government Household Survey) cited in 'Colombian Goals and Strategies for Achieving the Millenium Development Goals - 2015', Conpes Social (2005).

${ }^{7}$ Statistics for 2008 calculated by the National Deptartment of Statistics (DANE) and National Department of Planning (DNP) (2009).

${ }^{8}$ In 2003, 33 per cent of households headed by women were classified as poor, compared with 25 per cent of households headed by men. Source: MERDP, based on Encuesta de Calidad de Vida (2003).

${ }^{9}$ United Nations Office on Drugs and Crime (UNODC), 'Colombia: Coca Cultivation Survey', June 2006. Cited in ABColombia Group (April 2009) 'Fit for Purpose: How to make UK policy on Colombia more effective'.

${ }^{10}$ Despite extensive spraying of coca fields, between 2006 and 2007 coca cultivation increased by 27 per cent (UNODC).

${ }^{11}$ For example, in a recent scandal, the media reported that under the current government the Ministry of Agriculture has given away most of the public subsidies earmarked for small producers to relatives of politicians, famous actors, and other members of the elite. Source: www.cambio.com.co, 25 January 2010.

${ }^{12}$ J. Forero (2003) 'Peasant Economy and Food System in Colombia: Contributions for the discussion about food security', Bogotá. 
${ }^{13}$ Plan Maestro de Alimentos de Bogotá (Food Master Plan for Bogotá), Alcaldía Mayor de Bogotá.

${ }^{14}$ FAO (2005) 'The State of Insecurity in the World'. Statistics for 2000-02.

${ }^{15}$ Latin American Institute for Alternative Legal Services.

http://ilsa.org.co:81/node/141 (English); http://ilsa.org.co:81/node/155 (Spanish).

${ }^{16}$ Peasant and Rural Community Dialogue Committee.

${ }^{17}$ D. Yepes et al. (2005) 'Consumo de Alimentos en Bogotá. Déficit y Canasta Básica Recomendada (Food Consumption in Bogotá. Deficit and Recommended Food Basket'), ILSA.

18 'Food Supply Plan' refers to the plan for modifying the supply chain and refers to the way in which food is delivered to consumers (accessibility). The plan is part of the city's Food Security Policy, which is designed to ensure accessibility of food for consumers, as well as availability and nutritional value.

(c) Oxfam GB, April 2011

This paper was written by Aida Pesquera. We acknowledge the assistance of Jesús Aníbal Suárez, Andrés Bernal, Claire Harvey, David Wilson, Kirsty Wilson, Emma Donne and Abigail Humphries Robertson in its production, as well as the contributions made by ILSA, the CICC, and especially the thousands of small producers participating in the programme led by Oxfam, whose daily efforts were the main reason for its success. It is part of a series of papers written to inform public debate on development and humanitarian policy issues. The text may be freely used for the purposes of campaigning, education, and research, provided that the source is acknowledged in full.

For further information please email: apesquera@oxfam.org.co, or write to: Oxfam GB Colombia, Diagonal 35 No.5A-90, Bogotá, Colombia.

ISBN 978-1-84814-840-6. This paper is part of a set Small Farmers, Big Change: Achieving scale in the development of smallholder agriculture.

This paper is also available in Spanish.

\section{Oxfam GB}

Oxfam GB is a development, relief, and campaigning organization that works with others to find lasting solutions to poverty and suffering around the world. Oxfam GB is a member of Oxfam International.

Oxfam House

John Smith Drive

Cowley

Oxford

OX4 2JY

Tel: +44.(0)1865.473727

E-mail: enquiries@oxfam.org.uk

http://www.oxfam.org.uk 